\title{
Nutritional performance of cattle grazing on low-quality tropical forage supplemented with nitrogenous compounds and/or starch ${ }^{1}$
}

\section{Ísis Lazzarini ${ }^{2}$, Edenio Detmann ${ }^{3}$, Mário Fonseca Paulino ${ }^{3}$, Sebastião de Campos Valadares Filho $^{3}$, Rilene Ferreira Diniz Valadares ${ }^{4}$, Fabrício Albani Oliveira ${ }^{2}$, Poliana Teixeira da Silva ${ }^{2}$, William Lima Santiago dos Reis ${ }^{2}$}

\author{
${ }^{1}$ This paper was funded by CNPq, FAPEMIG (PPM) and INCT-Ciência Animal. \\ 2 Programa de Pós-Graduação em Zootecnia, Universidade Federal de Viçosa, Viçosa-MG, Brazil. \\ ${ }^{3}$ Departamento de Zootecnia, Universidade Federal de Viçosa, Viçosa, MG. Researcher of CNPq and INCT-Ciência Animal. \\ ${ }^{4}$ Departamento de Medicina Veterinária, Universidade Federal de Viçosa, Viçosa, MG, Brazil. Researcher of CNPq and INCT-Ciência Animal.
}

\begin{abstract}
The objective of this work was to evaluate the effects of protein and/or starch supplementation on the nutritional performance of cattle grazing on low-quality tropical forage. Five crossbred steers (Holstein $\times$ Gyr) with an average body weight $(\mathrm{BW})$ of $397 \mathrm{~kg}$ that were fitted with ruminal and abomasal cannulae were used. The animals were kept in individual signal-grass (Bracharia decumbens) paddocks. Five treatments were evaluated: 1 - control (without supplementation); 2 supplementation with $1 \mathrm{~g}$ of crude protein (CP) per kg of BW; 3 - supplementation with $2.5 \mathrm{~g}$ of starch per kg of BW; 4 - supplementation with $\mathrm{CP}$ and starch as described for treatments 2 and 3; and 5 - supplementation as described for treatment 4 but replacing the corn starch with a mixture of corn starch and nitrogenous compounds, thereby resulting in an energy supplement of $150 \mathrm{~g} \mathrm{CP} / \mathrm{kg}$ of dry matter. The experiment was performed according to a $5 \times 5$ Latin square design in a $2 \times 2+1$ factorial arrangement. The forage intake was not affected by any of the factors evaluated in this study. The production of microbial nitrogen in the rumen was not affected by nitrogen or starch supplementation. The apparent nitrogen balance was only increased when both starch and nitrogen were supplied. Supplementation with both starch and nitrogenous compounds for cattle grazing on low-quality tropical forage is characterized by an interactive metabolic effect that increases nitrogen accretion by the animals.
\end{abstract}

Key Words: forage intake, nitrogen balance, ruminal degradation, supplementation

\section{Introduction}

Most Brazilian beef cattle production systems have used tropical grasses as basal forage resources, as they provide low-cost energy from the potentially digestible fraction of neutral detergent fiber (NDF) (Detmann et al., 2008; Paulino et al., 2008).

However, tropical grasses are rarely available as an equilibrated diet for grazing cattle because they invariably exhibit a nutritional constraint that will limit pasture intake and digestibility. In this context, there is a demand to identify the main nutritional limitation of tropical pasture to avoid production constraints. After identification, the nutritional deficiencies can be reduced or eliminated via an adequate supplementation program, and the grazing cattle performance and the production system efficiency are increased as a result (Detmann et al., 2010).

During the low-rainfall season (dry season), there is a drastic decrease in the nutritional quality of tropical grasses, which is reflected by low crude protein (CP) and increased lignin content in the cell wall (Paulino et al., 2008). The limited CP availability provides the critical threshold for adequate microbial growth on the fibrous carbohydrates in basal forage (Henessy et al., 1983; Leng, 1990; Lazzarini et al., 2009). This CP deficiency implies poor utilization of potentially degradable cell wall by microorganisms and results in decreased intake and animal performance (Paulino et al., 2008).

Under these circumstances, several results obtained in the tropics have demonstrated that supplementation with nitrogenous compounds is the primary nutritional tool to improve the utilization of low-quality forage by grazing cattle (Henessy et al., 1983; Leng, 1990; Sampaio et al., 2010; Souza et al., 2010).

Detrimental effects on low-quality forage utilization can be observed when nonfibrous carbohydrates (NFC) are introduced in the supplements (Souza et al., 2010). In this case, the decrease in ruminal fiber degradation is associated with competition for essential nutrients between fibrolytic and nonfibrolytic microbial species that would be more prominent under conditions of low nitrogen availability (El-Shazly et al., 1961; Costa, 2006). 
However, research conducted in the tropics has indicated that simultaneous nitrogen and energy supplementation could exert interactive effects on the metabolism of nitrogenous compounds and increase nitrogen assimilation in the rumen (Lee et al., 1987; Detmann et al., 2010; Souza et al., 2010). Nevertheless, information about the effects of the interactions between supplemental nitrogen and energy on the utilization of low-quality forage by grazing beef cattle remains scarce in the tropics.

Therefore, the objective of this work was to evaluate the effects of supplementation with nitrogenous compounds and/or NFC (starch) on the intake, digestibility and nitrogen metabolism by cattle grazing on low-quality tropical forage.

\section{Material and Methods}

The experiment was performed from July to September 2008 (dry season) in Viçosa, Minas Gerais, Brazil. Five crossbred steers (Holstein $\times$ Gyr) with an average body weight (BW) of $397 \pm 13 \mathrm{~kg}$ were surgically fitted with ruminal and abomasal cannulae and kept in individual signalgrass (Brachiaria decumbens) paddocks of approximately 0.34 ha. Water and a mineral mixture were available to the steers at all times. All surgical and animal care procedures were approved by the University Animal Care Committee. Ruminal and abomasal fistulae and their surrounding areas were cleaned routinely during the experiment.

Five treatments were evaluated: 1 - control without supplementation; 2 - supplementation with $1 \mathrm{~g}$ of $\mathrm{CP}$ per $\mathrm{kg}$ of BW; 3 - supplementation with $2.5 \mathrm{~g}$ of starch (Amisol $3408^{\circledR}$, CornProducts Co.) per kg of BW; 4 - supplementation with nitrogenous compounds and cornstarch as described for treatments 2 and 3; and 5 - supplementation as described for treatment 4 but replacing the corn starch with a mixture of corn starch and nitrogenous compounds, thereby resulting in an energy supplement of $150 \mathrm{~g} \mathrm{CP} / \mathrm{kg}$ of dry matter (DM). The supplement amount was calculated based on BW at the beginning of each experimental period. It was placed in two portions of equal weight in the rumen of the animals daily at $06 \mathrm{~h} 00$ and $18 \mathrm{~h} 00$ during the experimental period.

A mixture of urea, ammonium sulfate and albumin (Maximus, Arve Alimentos Co.) was used as a source of nitrogenous compounds at a ratio of 4.5:0.5:1.0. The nitrogenous compound supplement lacked carbohydrate content, thereby allowing the supplementation effects with nitrogenous compounds to be evaluated without any supplementary source of fiber or energy interfering with the measurements. Albumin was included in the supplement to meet the microbial requirements for true degradable protein and to supply essential substrates, such as branched-chain volatile fatty acids.

The experiment consisted of five 15-day experimental periods. The first 5 days of each experimental period were used to adapt the animals to the supplements.

The available forage in the pasture was estimated by cutting five square areas $(0.5 \times 0.5 \mathrm{~m})$ in each paddock that were randomly chosen on the first day of the experimental period. The samples were oven-dried $\left(60^{\circ} \mathrm{C}\right)$, processed in a knife mill (1-mm) and analyzed for DM content (Detmann et al., 2012). The average forage availability during the experiment was $2.80 \pm 0.31 \mathrm{t}$ of $\mathrm{DM} / \mathrm{ha}$.

The evaluation of the consumed forage was performed with hand-plucked samples that were obtained on the first, fourth and seventh days of each experimental period. The samples were oven-dried $\left(60^{\circ} \mathrm{C}\right)$ and processed in a knife mill (1- and 2-mm). Composite samples were produced for each paddock and experimental period.

Fecal excretion was estimated using titanium dioxide as an external marker. Titanium dioxide was infused $(20 \mathrm{~g} /$ day $)$ into the rumen of each animal at $12 \mathrm{~h} 00$ from the first to the eighth day of each experimental period. Fecal samples were taken from the rectum of each animal according to the following schedule: sixth day $-08 \mathrm{~h} 00$ and $14 \mathrm{~h} 00$; seventh day $-10 \mathrm{~h} 00$ and $16 \mathrm{~h} 00$; and eighth day $-12 \mathrm{~h} 00$ and $18 \mathrm{~h} 00$. Concurrently with fecal sampling, samples of the abomasal contents were taken.

The samples of feces and abomasal contents were ovendried $\left(60{ }^{\circ} \mathrm{C}\right)$ and processed in a knife mill (1 and $\left.2 \mathrm{~mm}\right)$. Next, composite samples were produced for each animal and experimental period.

To evaluate the ruminal ammonia nitrogen (RAN) concentration and $\mathrm{pH}$, samples of ruminal fluid were taken on the ninth day of each experimental period at $06 \mathrm{~h} 00$, $12 \mathrm{~h} 00,18 \mathrm{~h} 00$ and $24 \mathrm{~h} 00$. The samples were collected manually from the liquid:solid interface of the rumen mat, filtered through a triple layer of cheesecloth and subjected to $\mathrm{pH}$ assessment using a digital potentiometer (TEC-3PMP, Tecnal ${ }^{\circledR}$ ). A $40 \mathrm{~mL}$ aliquot was subsequently separated, fixed with $1 \mathrm{~mL}$ of $\mathrm{H}_{2} \mathrm{SO}_{4}(1: 1)$ and frozen $\left(-20^{\circ} \mathrm{C}\right)$.

The in situ incubation to estimate the rumen degradation parameters of the NDF was performed between the 10th and 15th days of each experimental period. The pasture samples obtained by hand-pluck sampling on the first day of each experimental period were processed in a knife mill $(2-\mathrm{mm})$ and placed in nonwoven textile $\left(100 \mathrm{~g} / \mathrm{m}^{2}\right) \mathrm{bags}$ (Casali, 2006) at a ratio of $20 \mathrm{mg} \mathrm{DM} / \mathrm{cm}^{2}$ of bag surface. The bags, utilized in duplicate for each incubation time, were placed into the rumen of the animals. The following 
incubation times were used: $0,3,6,9,12,24,36,48,60,72$, 96 and 120 hours. After incubation, the bags were cleaned with tap water and oven-dried $\left(60^{\circ} \mathrm{C}\right)$.

On the 15th day of each experimental period, urine spot samples were obtained before (06h00) and approximately 6 hours (12h00) after the morning supplementation. The samples were filtered through cheesecloth, and a $10 \mathrm{~mL}$ aliquot was separated, diluted with $40 \mathrm{~mL} \mathrm{H}_{2} \mathrm{SO}_{4}(0.036 \mathrm{~N})$ and frozen $\left(-20^{\circ} \mathrm{C}\right)$.

Blood was collected from the jugular vein of each animal on the 15th day (4 hours after the morning supplementation) using test tubes containing separator gel and coagulation accelerator (BD Vacuntainer ${ }^{\circledR}$ SST II Advance). The samples were centrifuged at $2700 \times \mathrm{g}$ for $20 \mathrm{~min}$ to obtain the serum, which was frozen thereafter $\left(-20^{\circ} \mathrm{C}\right)$.

Forage, fecal and abomasal content samples (processed to pass through a 1-mm screen sieve) were analyzed for $\mathrm{DM}$, organic matter $(\mathrm{OM}), \mathrm{CP}$ and ether extract (EE) contents, according to the methods of INCT-Ciência Animal (Detmann et al., 2012). In the NDF analysis, the samples were treated with heat-stable alpha amylase without using sodium sulfite and were corrected for residual ash and protein (NDFap; Detmann et al., 2012). The lignin content was obtained by cellulose solubilization using sulfuric acid. The supplement samples were analyzed for DM, OM and $\mathrm{CP}$ content as described above (Table 1).

The NFC contents ( $\mathrm{g} / \mathrm{kg} \mathrm{DM})$ were estimated following the suggestions of Detmann \& Valadares Filho (2010), as follows:

$N F C=O M-[E E+N D F a p+(C P-C P u+U)]$

where $\mathrm{CPu}$ is the $\mathrm{CP}$ content from urea $(\mathrm{g} / \mathrm{kg} \mathrm{DM})$ and $\mathrm{U}$ is the urea content $(\mathrm{g} / \mathrm{kg} \mathrm{DM})$. The other terms were previously defined (g/kg DM).

The fecal samples were evaluated for titanium dioxide content according to the colorimetric method (Detmann et al.,
2012). The fecal excretion of DM was obtained as the ratio of the daily dose to the fecal content of the marker.

The estimates of pasture intake were obtained using indigestible NDF (iNDF) as an internal marker. The contents of iNDF were estimated in the samples (processed to pass a 2-mm screen sieve) using a 240-hour in situ incubation procedure as suggested by Casali (2006). The intake was obtained as follows:

$D M I=f D M I+s D M I=\frac{(F E \times i N D F f c)}{i N D F f o r}+s D M I$

where DMI is the dry matter intake ( $g /$ day), fDMI is the DM intake from forage ( $\mathrm{g} /$ day), sDMI is the DM intake from the supplement ( $g$ /day), FE is the fecal excretion of $\mathrm{DM}$ (g/day), iNDFfc is the fecal content of iNDF (g/g DM) and iNDFfor is the forage content of iNDF ( $/ \mathrm{g} D M)$.

The abomasal flow was calculated as the ratio of the intake to the abomasal content of iNDF.

The RAN content in the ruminal fluid samples was determined using the micro-Kjeldahl system without acid digestion and after distillation with potassium hydroxide $(2 \mathrm{~N})$, after previous centrifugation of the sample to $1000 \times g$ for $15 \mathrm{~min}$. The concentrations obtained at the different sampling times were combined by animal and period to obtain a single value that represented the average daily RAN concentration. Ruminal $\mathrm{pH}$ values were combined in a similar manner.

After thawing, the urine samples were grouped by animal and experimental period. The creatinine, uric acid and allantoin contents in urine were estimated using modified Jaffé (Bioclin K016-1), LCF enzymaticcolorimetric (Human 10687) and colorimetric (Chen \& Gomes, 1992) methods, and the total nitrogen content was estimated by the Kjeldahl method (Detmann et al., 2012). The urea concentrations in blood serum were obtained by the enzymatic-colorimetric (Bioclin K047) method.

Table 1 - Chemical composition of pasture and supplements

\begin{tabular}{|c|c|c|c|c|c|}
\hline \multirow{2}{*}{ Item } & \multicolumn{4}{|c|}{ Supplements } & \multirow{2}{*}{ Pasture $^{4}$} \\
\hline & Nitrogen & Starch & Nitrogen + Starch & Additional supplement & \\
\hline Dry matter ${ }^{1}$ & 943.3 & 873.7 & 908.5 & 907.3 & $363.5 \pm 17.9$ \\
\hline Crude protein ${ }^{2}$ & 1962.3 & 0.0 & 560.7 & 677.3 & $82.4 \pm 2.4$ \\
\hline Ether extract ${ }^{2}$ & - & - & - & - & $15.4 \pm 0.6$ \\
\hline Neutral detergent fiber corrected for ash and protein ${ }^{2}$ & - & - & - & - & $600.9 \pm 6.6$ \\
\hline Nonfibrous carbohydrates ${ }^{2}$ & 37.4 & 999.2 & 950.9 & 944.3 & $209.7 \pm 5.6$ \\
\hline $\operatorname{Lignin}^{2}$ & - & - & - & - & $48.6 \pm 1.7$ \\
\hline Indigestible neutral detergent fiber ${ }^{2}$ & - & - & - & - & $255.0 \pm 8.1$ \\
\hline
\end{tabular}


The total urinary volume was estimated using the ratio of creatinine excretion per unit of $\mathrm{BW}$ to its concentration in the urine (Chizzotti et al, 2006). The excretion of purine derivatives was calculated from the sum of the quantities of allantoin and uric acid excreted in urine. From this finding, the absorbed purines were calculated by the following equation (Barbosa et al., 2011):

$$
A P=\frac{P D-0.3 \times B W^{0.75}}{0.80}
$$

where AP is the amount of absorbed purines (mmol/day), $\mathrm{PD}$ is the amount of excreted purine derivatives (mmol/ day), 0.80 is the recovery of absorbed purines as purine derivatives in the urine $(\mathrm{mmol} / \mathrm{mmol})$ and 0.3 is the excretion of endogenous purine derivatives in the urine per unit of metabolic size (mmol).

The microbial synthesis of nitrogenous compounds in the rumen (NMIC, g/day) was estimated as a function of the absorbed purines and the $\mathrm{N}_{\mathrm{RNA}}: \mathrm{N}_{\text {TOTAL }}$ ratio of the microorganisms (Chen \& Gomes, 1992), as follows:

$$
N M I C=\frac{70 \times A P}{0.83 \times R \times 1000}
$$

where $\mathrm{R}$ is the $\mathrm{N}_{\mathrm{RNA}}: \mathrm{N}_{\text {TOTAL }}$ ratio in the microorganisms $(\mathrm{mg} / \mathrm{mg}), 70$ is the nitrogen content in purines $(\mathrm{mg} / \mathrm{mol})$ and 0.83 is the intestinal digestibility of the microbial purines $(\mathrm{mg} / \mathrm{mg})$.

An $\mathrm{N}_{\mathrm{RNA}}$ : $\mathrm{N}_{\text {TOTAL }}$ ratio of 0.139 was used. This estimate represents the average obtained from experiments with cattle fed low-quality tropical forage (Figueiras, 2008).

The degradation residues were evaluated for NDF content by using a fiber analyzer (Ankom $220^{\circledR}$ ).

The NDF residues obtained in all of the experimental periods for each treatment were evaluated as one dataset. Thus, one curve adjustment was done for each treatment. The NDF degradation profiles were interpreted using a logistic model (Van Milgen et al., 1991) as follows:

$R_{t}=p d N D F \times(1+\lambda \times t) \times \exp (-\lambda \times \mathrm{t})+u N D F$ where $R_{t}$ is the nondegraded residue of NDF at time " $t$ " $(\mathrm{g} / 100 \mathrm{~g} \mathrm{NDF}), \mathrm{pdNDF}$ is the potentially degradable fraction of NDF ( $\mathrm{g} / 100 \mathrm{~g}$ NDF), $\mathrm{uNDF}$ is the nondegradable fraction of NDF ( $\mathrm{g} / 100 \mathrm{~g} \mathrm{NDF})$ and $\lambda$ is the common rate of lag and degradation $\left(\mathrm{h}^{-1}\right)$.

The discrete lag for fiber degradation (LAG, h) was estimated as:

$$
L A G=\frac{R(0)-R\left(t_{i}\right)}{R^{\prime}\left(t_{i}\right)}+t_{i}
$$

where $R(0)$ is the nondegraded residue of NDF at $t=0$ ( $\mathrm{g} / 100 \mathrm{~g} \mathrm{NDF}), \mathrm{R}\left(\mathrm{t}_{\mathrm{i}}\right)$ is the nondegraded residue of NDF at the inflection of the fitted degradation profile (g/100 $\mathrm{g} \mathrm{NDF}$ ), $\mathrm{R}^{\prime}\left(\mathrm{t}_{\mathrm{i}}\right)$ is the mathematical derivative of the fitted degradation profile at the inflection point (maximal degradation rate) $\left(h^{-1}\right)$ and $t_{i}$ is the time when the inflection point occurs $(h)$ as defined by $t_{i}=1 / \lambda$ (Van Milgen et al., 1991).

The experiment was analyzed following a $5 \times 5$ Latin square design according to a $2 \times 2+1$ factorial arrangement (with or without nitrogenous compounds and with or without starch, plus the additional treatment). After the analysis of variance, the treatments were compared using contrasts (Table 2). All statistical procedures were performed using the GLM procedure of SAS (Statistical Analysis System, version 9.1) using $\alpha=0.10$.

The nonlinear adjustments of the models described in Equation (5) followed the Gauss-Newton iterative algorithm, which is implemented in the NLIN procedure of SAS (Statistical Analysis System, version 9.1). After adjusting, the treatments were compared using the $\chi^{2}$ distribution according to the nonlinear identity test described by Regazzi (2003). In this case, the overall difference among all treatments was evaluated. The test was performed only on parameter $\lambda$. The pdNDF and uNDF fractions (Equation 5) were not statistically evaluated because they are considered inherent characteristics of the substrate (Detmann et al., 2008). We used 0.10 as the asymptotic critical probability for type I error.

\section{Results}

The intake of DM, DM from forage, OM, EE, NDF, digested NDF (DNDF) and iNDF was not affected $(\mathrm{P}>0.10)$

\begin{tabular}{|c|c|c|c|c|c|}
\hline \multirow{2}{*}{ Contrast } & \multicolumn{5}{|c|}{ Treatments } \\
\hline & Control & Nitrogen & Starch & Nitrogen + Starch & Additional supplement \\
\hline & \multicolumn{5}{|c|}{ Orthogonal set } \\
\hline Nitrogen & +1 & -1 & +1 & -1 & 0 \\
\hline Starch & +1 & +1 & -1 & -1 & 0 \\
\hline \multirow[t]{2}{*}{ Nitrogen $\times$ Starch } & +1 & -1 & -1 & +1 & 0 \\
\hline & \multicolumn{5}{|c|}{ Additional contrast } \\
\hline Additional comparison & 0 & 0 & 0 & +1 & -1 \\
\hline
\end{tabular}
by any type of supplement (Table 3). Nevertheless,

Table 2 - Distribution of coefficients employed in the contrasts among treatments 
supplementation with nitrogenous compounds increased the intake of DM from forage, NDF and DNDF $(\mathrm{kg} / \mathrm{d})$ by 19.3 , 20.6 and $27.9 \%$, respectively, compared with the control treatment, albeit without significance ( $\mathrm{P}>0.10$; Table 3$)$.

An interaction effect between nitrogen and starch supplementation was observed for CP intake $(\mathrm{P}<0.04)$. Analysis of this effect revealed that nitrogen supplementation increased $\mathrm{CP}$ intake $(\mathrm{P}<0.10)$ with or without starch supplementation, although simultaneous nitrogen and starch supplementation resulted in a higher $\mathrm{CP}$ intake than nitrogen supplementation alone $(\mathrm{P}<0.10)$. When nitrogen was not supplied, starch supplementation did not affect $(\mathrm{P}>0.10) \mathrm{CP}$ intake (Table 4). Moreover, supplying additional nitrogenous compounds to animals supplemented with both nitrogen and starch (additional treatment) increased $(\mathrm{P}<0.02) \mathrm{CP}$ intake (Table 3$)$.

Non-fibrous carbohydrate intake was increased $(\mathrm{P}<0.01)$ by starch supplementation but not by nitrogen supplementation ( $\mathrm{P}>0.10$; Table 3$)$.

The intake of digested OM was not affected by starch or nitrogen, neither alone nor in combination $(\mathrm{P}>0.10)$. Nonetheless, digested OM intake was increased $(\mathrm{P}<0.08)$ when additional nitrogen was supplied to the animals supplemented with both nitrogen and starch (Table 3 ).

The intake of total digestible nutrients (TDN) was increased $(\mathrm{P}<0.04)$ by both types of supplements, but there was no interaction effect $(\mathrm{P}>0.10)$. Total digestible nutrient intake was also increased $(\mathrm{P}<0.05)$ by supplying additional nitrogen to the animals supplemented with both nitrogen and starch (Table 3).

Table 4 - Evaluation of the interaction between nitrogen and starch supplementation

\begin{tabular}{lcc}
\hline \multirow{2}{*}{ Nitrogen } & \multicolumn{2}{c}{ Starch } \\
\cline { 2 - 3 } & \multicolumn{2}{c}{ Without } \\
Without & Crude protein $(\mathrm{CP})$ intake $(\mathrm{kg} / \mathrm{d})$ \\
With & $0.570 \mathrm{Ba}$ & $0.563 \mathrm{Ba}$ \\
& $0.988 \mathrm{Ab}$ & $1.335 \mathrm{Aa}$ \\
Without & Ruminal digestibility of CP $(\mathrm{g} / \mathrm{g})$ \\
With & $-0.331 \mathrm{Ba}$ & $-0.621 \mathrm{Bb}$ \\
& $0.065 \mathrm{Ab}$ & $0.290 \mathrm{Aa}$ \\
Without & \multicolumn{1}{c}{ Total digestibility of CP $(\mathrm{g} / \mathrm{g})$} \\
With & $0.312 \mathrm{Ba}$ & $0.228 \mathrm{Ba}$ \\
& $0.535 \mathrm{Ab}$ & $0.673 \mathrm{Aa}$ \\
Without & \multicolumn{2}{c}{ Nitrogen intake $(\mathrm{g} / \mathrm{d})$} \\
With & $91.3 \mathrm{Ba}$ & $90.1 \mathrm{Ba}$ \\
& $158.2 \mathrm{Ab}$ & $213.6 \mathrm{Aa}$ \\
Without & Ruminal ammonia nitrogen $(\mathrm{mg} / \mathrm{dL})$ \\
With & $4.46 \mathrm{Ba}$ & $4.06 \mathrm{Aa}$ \\
& $17.13 \mathrm{Aa}$ & $8.32 \mathrm{Ab}$ \\
Without & Apparent nitrogen balance $(\mathrm{g} / \mathrm{d})$ \\
With & $0.1 \mathrm{Aa}$ & $-6.1 \mathrm{Ba}$ \\
& $13.8 \mathrm{Ab}$ & $69.6 \mathrm{Aa}$ \\
Without & Serum urea nitrogen $(\mathrm{mg} / \mathrm{dL})$ \\
With & $13.7 \mathrm{Ba}$ & $6.4 \mathrm{Bb}$ \\
\hline & $20.1 \mathrm{Ab}$ & $26.2 \mathrm{Aa}$ \\
\hline
\end{tabular}

A,B Means in the same column followed by different letters are different $(\mathrm{P}<0.10)$. a,b Means in the same row followed by different letters are different $(\mathrm{P}<0.10)$.

Table 3 - Least square means and coefficients of variation (CV) for daily voluntary intake according to the treatments

\begin{tabular}{|c|c|c|c|c|c|c|c|c|c|c|}
\hline \multirow{2}{*}{ Item } & \multicolumn{5}{|c|}{ Treatments } & \multirow{2}{*}{ CV $(\%)$} & \multicolumn{4}{|c|}{ P-value } \\
\hline & $\mathrm{C}$ & NIT & ST & $\mathrm{NIT}+\mathrm{ST}$ & $\mathrm{AD}$ & & $\mathrm{N}$ & $\mathrm{S}$ & $\mathrm{N} \times \mathrm{S}$ & ADIT \\
\hline & \multicolumn{10}{|c|}{$\mathrm{kg} / \mathrm{d}$} \\
\hline DM & 6.824 & 8.320 & 7.728 & 8.102 & 9.519 & 22.3 & 0.270 & 0.679 & 0.501 & 0.239 \\
\hline DMF & 6.824 & 8.141 & 6.720 & 6.690 & 8.100 & 24.6 & 0.438 & 0.351 & 0.417 & 0.237 \\
\hline $\mathrm{OM}$ & 6.209 & 7.546 & 7.117 & 7.462 & 8.789 & 22.3 & 0.278 & 0.588 & 0.516 & 0.229 \\
\hline $\mathrm{CP}$ & 0.570 & 0.988 & 0.563 & 1.335 & 1.654 & 16.2 & $<0.001$ & 0.041 & 0.034 & 0.010 \\
\hline $\mathrm{EE}$ & 0.091 & 0.118 & 0.100 & 0.113 & 0.140 & 29.4 & 0.201 & 0.885 & 0.622 & 0.220 \\
\hline NDFap & 4.015 & 4.841 & 4.108 & 4.060 & 4.773 & 23.5 & 0.413 & 0.468 & 0.359 & 0.293 \\
\hline NFC & 1.421 & 1.778 & 2.344 & 2.701 & 3.126 & 21.3 & 0.125 & 0.001 & 0.998 & 0.191 \\
\hline DOM & 2.418 & 3.156 & 3.386 & 3.578 & 4.793 & 28.2 & 0.309 & 0.138 & 0.544 & 0.073 \\
\hline DNDF & 1.974 & 2.525 & 1.993 & 1.917 & 2.594 & 29.2 & 0.423 & 0.327 & 0.297 & 0.122 \\
\hline TDN & 2.253 & 3.304 & 3.376 & 4.334 & 5.715 & 25.8 & 0.040 & 0.030 & 0.917 & 0.045 \\
\hline \multirow[t]{2}{*}{ iNDF } & 1.667 & 2.048 & 1.804 & 1.831 & 1.823 & 22.9 & 0.299 & 0.836 & 0.364 & 0.978 \\
\hline & \multicolumn{10}{|c|}{$\mathrm{g} / \mathrm{kg} \mathrm{BW}$} \\
\hline DM & 17.4 & 21.1 & 18.9 & 20.0 & 23.1 & 22.3 & 0.255 & 0.935 & 0.517 & 0.280 \\
\hline DMF & 17.4 & 20.6 & 16.4 & 16.5 & 19.7 & 24.8 & 0.415 & 0.225 & 0.441 & 0.282 \\
\hline $\mathrm{OM}$ & 15.8 & 19.1 & 17.4 & 18.3 & 21.4 & 22.3 & 0.263 & 0.833 & 0.535 & 0.268 \\
\hline NDFap & 10.2 & 12.3 & 10.0 & 10.0 & 11.6 & 23.9 & 0.396 & 0.313 & 0.389 & 0.293 \\
\hline iNDF & 4.2 & 5.2 & 4.4 & 4.5 & 4.4 & 23.3 & 0.290 & 0.628 & 0.399 & 0.913 \\
\hline
\end{tabular}

DM - dry matter; DMF - DM from forage; OM - organic matter; CP - crude protein; EE - ether extract; NDFap - neutral detergent fiber corrected for ash and protein; NFC nonfibrous carbohydrates; DOM - digested OM; DNDF - digested NDFap; TDN - total digestible nutrients; iNDF - indigestible neutral detergent fiber.

C - control (without supplementation); NIT - supplementation with nitrogenous compounds; ST - supplementation with starch; NIT+ST - supplementation with nitrogenous compounds and starch; $\mathrm{AD}$ - supplementation with nitrogenous compounds and a mixture of starch and nitrogen which presented $150 \mathrm{CP} / \mathrm{kg} \mathrm{DM}$ (additional treatment).

$\mathrm{N}$ - effect of supplementation with nitrogenous compounds; $\mathrm{S}$ - effect of supplementation with starch; $\mathrm{N} \times \mathrm{S}$ - interaction between nitrogenous compounds and starch; ADIT additional comparison between treatments NIT+ST and AD. 
The supplementation with nitrogenous compounds increased $(\mathrm{P}<0.01)$ the dietary level of TDN, but it did not affect $(\mathrm{P}>0.10)$ the total digestibility coefficients with the exception of CP digestibility, which exhibited an interaction effect between nitrogen and starch $(\mathrm{P}<0.02)$. Additionally, starch supplementation improved $(\mathrm{P}<0.01)$ the TDN level and total digestibility of the OM and NFC. Supplying additional nitrogen to the animals supplemented with both nitrogen and starch increased the TDN level $(\mathrm{P}<0.01)$ and total digestibility of the $\mathrm{OM}$ and $\mathrm{NDF}(\mathrm{P}<0.03$; Table 5).

Analysis of the interaction effect on the total digestibility of CP revealed that nitrogen supplementation increased the digestibility of this component $(\mathrm{P}<0.10)$ in the presence or absence of starch. However, starch increased $\mathrm{CP}$ digestibility $(\mathrm{P}<0.10)$ only when nitrogen was also supplied (Table 4).

An interaction effect between nitrogen and starch $(\mathrm{P}<0.02)$ on the ruminal digestibility of $\mathrm{CP}(\mathrm{RDCP})$ was observed. Analysis of this effect revealed that nitrogen supplementation increased the $\operatorname{RDCP}(\mathrm{P}<0.10)$ in the presence or absence of starch and changed the estimates from negative to positive. Starch supplementation decreased $(\mathrm{P}<0.10)$ the RDCP in the absence of nitrogen supplementation and increased $(\mathrm{P}<0.10)$ the RDCP in the presence of nitrogen supplementation (Table 4). Additional CP supplementation to the animals supplemented with both nitrogen and starch increased the RDCP by 0.165 , although not significantly $(\mathrm{P}>0.10$; Table 5$)$.

Starch supplementation increased $(\mathrm{P}<0.01)$ the ruminal digestibility of the NFC but decreased $(\mathrm{P}<0.09)$ the ruminal utilization of the NDF. Additional CP supplementation to the animals supplemented with both nitrogen and starch increased $(\mathrm{P}<0.03)$ the ruminal digestibility of the $\mathrm{OM}$ (Table 5).

The ruminal $\mathrm{pH}$ was decreased $(\mathrm{P}<0.03)$ by starch supplementation, but it was not affected $(\mathrm{P}>0.10)$ by nitrogen supplementation (Table 6).

There was an interaction effect $(\mathrm{P}<0.05)$ between nitrogen and starch on the nitrogen intake and the RAN concentration (Table 6). The nitrogen intake exhibited the same pattern as the CP intake (Table 4). Moreover, analysis of interaction indicated that the RAN concentration was increased $(\mathrm{P}<0.10)$ by nitrogen supplementation in the absence of starch, but RAN levels were not further increased by simultaneous supplementation $(\mathrm{P}>0.10)$. Starch supplementation did not alter $(\mathrm{P}>0.10)$ the RAN concentration in the absence of nitrogen supplementation, but the RAN concentration $(\mathrm{P}<0.10)$ was lower with simultaneous starch and nitrogen supplementation than with nitrogen supplementation alone (Table 4).

The fecal excretion of nitrogen was not affected $(\mathrm{P}>0.10)$ by any treatment. The urinary nitrogen (UN) level was increased $(\mathrm{P}<0.01)$ by nitrogen supplementation, but there was no effect of starch supplementation and no effects of interaction between nitrogen and starch $(\mathrm{P}>0.10$; Table 6).

An effect of the interaction between nitrogen and starch supplementation was observed for the apparent nitrogen balance (NB) $(\mathrm{P}<0.07$; Table 6). The NB estimates were increased $(\mathrm{P}<0.10)$ only when both starch and nitrogen were supplied together (Table 4). Despite the interaction effect on the NB, the relative NB (RNB; g of retained nitrogen per $g$ of ingested nitrogen) was increased $(\mathrm{P}<0.03)$ only by nitrogen supplementation (Table 6).

Table 5 - Least square means and coefficients of variation (CV) for ruminal and total digestibility coefficients (g/g) and dietary level of total digestible nutrients $(\mathrm{g} / \mathrm{kg} \mathrm{DM})$ according to the treatments

\begin{tabular}{|c|c|c|c|c|c|c|c|c|c|c|}
\hline \multirow{2}{*}{ Item } & \multicolumn{5}{|c|}{ Treatments } & \multirow{2}{*}{$\mathrm{CV}(\%)$} & \multicolumn{4}{|c|}{ P-value } \\
\hline & $\mathrm{C}$ & NIT & ST & $\mathrm{NIT}+\mathrm{ST}$ & $\mathrm{AD}$ & & $\mathrm{N}$ & $\mathrm{S}$ & $\mathrm{N} \times \mathrm{S}$ & ADIT \\
\hline & \multicolumn{10}{|c|}{ Ruminal $^{1}$} \\
\hline OM & 0.218 & 0.260 & 0.243 & 0.299 & 0.419 & 23.5 & 0.153 & 0.336 & 0.820 & 0.026 \\
\hline $\mathrm{CP}$ & -0.331 & 0.065 & -0.621 & 0.290 & 0.455 & 477.6 & $<0.001$ & 0.702 & 0.010 & 0.206 \\
\hline NDFap & 0.427 & 0.449 & 0.368 & 0.379 & 0.467 & 17.1 & 0.620 & 0.085 & 0.877 & 0.107 \\
\hline \multirow[t]{2}{*}{ NFC } & -0.098 & -0.104 & 0.251 & 0.374 & 0.496 & 100.9 & 0.524 & $<0.001$ & 0.486 & 0.379 \\
\hline & \multicolumn{10}{|c|}{ Total $^{1}$} \\
\hline OM & 0.388 & 0.411 & 0.472 & 0.476 & 0.545 & 9.3 & 0.506 & 0.002 & 0.634 & 0.025 \\
\hline $\mathrm{CP}$ & 0.312 & 0.535 & 0.228 & 0.673 & 0.737 & 16.3 & $<0.001$ & 0.469 & 0.010 & 0.241 \\
\hline NDFap & 0.495 & 0.517 & 0.478 & 0.463 & 0.543 & 9.8 & 0.870 & 0.129 & 0.411 & 0.023 \\
\hline NFC & 0.117 & 0.096 & 0.539 & 0.559 & 0.597 & 33.1 & 0.991 & $<0.001$ & 0.723 & 0.641 \\
\hline TDN & 338 & 395 & 433 & 537 & 601 & 7.0 & $<0.001$ & $<0.001$ & 0.131 & 0.009 \\
\hline
\end{tabular}

OM - organic matter; CP - crude protein; NDFap - neutral detergent fiber corrected for ash and protein; NFC - nonfibrous carbohydrates; TDN total digestible nutrients.

C - control (without supplementation); NIT - supplementation with nitrogenous compounds; ST - supplementation with starch; NIT+ST - supplementation with nitrogenous compounds and starch; AD - supplementation with nitrogenous compounds and a mixture of starch and nitrogen which presented $150 \mathrm{CP} / \mathrm{kg} \mathrm{DM}$ (additional treatment).

$\mathrm{N}$ - effect of supplementation with nitrogenous compounds; $\mathrm{S}$ - effect of supplementation with starch; $\mathrm{N} \times \mathrm{S}$ - interaction between nitrogenous compounds and starch; ADIT additional comparison between treatments NIT+ST and AD.

${ }^{1}$ Digestibility coefficients were calculated as $\mathrm{g}$ of digested material $/ \mathrm{g}$ of ingested material. 
An interaction effect between nitrogen and starch supplementation $(\mathrm{P}<0.01)$ was observed on the concentration of serum urea nitrogen (SUN) (Table 6). The SUN concentration was increased $(\mathrm{P}<0.10)$ by supplementation with nitrogenous compounds both in the absence and presence of starch supplementation. The SUN estimates were increased by starch supplementation in the presence of nitrogen supplementation, but they were decreased $(\mathrm{P}<0.10)$ by starch in the absence of nitrogen (Table 4).

The NMIC was not affected $(\mathrm{P}>0.10)$ by nitrogen or starch supplementation. The same pattern was verified for the efficiency of microbial synthesis in the rumen $(\mathrm{P}>0.10)$, whose average estimate was $127.0 \mathrm{~g}$ microbial $\mathrm{CP}$ per $\mathrm{kg}$ of TDN (Table 6).

Additional CP supplementation to the animals already supplemented with nitrogen and starch increased the nitrogen intake $(\mathrm{P}<0.02), \mathrm{UN}(\mathrm{P}<0.01)$ and NMIC $(\mathrm{P}<0.09)$, but did not affect $(\mathrm{P}>0.10)$ the other variables presented in Table 6 .

The estimates of the common fractional rate of lag and degradation $(\lambda)$ were affected by the treatments $(\mathrm{P}<0.01)$. The more prominent effect was verified with exclusive starch supplementation, which decreased the $\lambda$ estimate by
$34.6 \%$ compared with that of the control. Such effects were reflected in the discrete lag, which was increased by $53 \%$ with starch supplementation (Table 7).

\section{Discussion}

Generally, the microbial activity detected on fibrous compounds depends on the nitrogen availability in the rumen. When nitrogen is supplied to animals fed lowquality forage, as is observed during the dry season, there will be an incremental growth of fibrolytic microorganisms that will improve the ruminal degradation of the NDF, the voluntary intake of pasture and the energy extraction from the fibrous carbohydrates of forage (Paulino et al., 2008; Detmann et al., 2010).

Although nitrogen supplementation increased both the pasture and NDF intake by $20 \%$, this effect was not significant (Table 3), which apparently contradicts the assumption presented above.

The results obtained in the tropics demonstrate that the response to an exclusive supplementation with nitrogenous compounds depends on the protein level in the diet. When cattle are fed low-quality forage, voluntary intake and the intake of digested components are stimulated

Table 6 - Least square means and coefficients of variation $(\mathrm{CV})$ for ruminal $\mathrm{pH}$ and other variables according to the treatments

\begin{tabular}{|c|c|c|c|c|c|c|c|c|c|c|}
\hline \multirow{2}{*}{ Item } & \multicolumn{5}{|c|}{ Treatments } & \multirow{2}{*}{$\mathrm{CV}(\%)$} & \multicolumn{4}{|c|}{$\mathrm{P}$-value } \\
\hline & $\mathrm{C}$ & NIT & ST & $\mathrm{NIT}+\mathrm{ST}$ & $\mathrm{AD}$ & & $\mathrm{N}$ & $\mathrm{S}$ & $\mathrm{N} \times \mathrm{S}$ & ADIT \\
\hline $\mathrm{pH}$ & 7.36 & 7.36 & 7.21 & 7.28 & 7.23 & 1.4 & 0.542 & 0.026 & 0.542 & 0.533 \\
\hline RAN & 4.46 & 17.13 & 4.06 & 8.32 & 11.91 & 46.5 & 0.001 & 0.033 & 0.048 & 0.247 \\
\hline NI & 91.3 & 158.2 & 90.1 & 213.6 & 267.1 & 17.3 & $<0.001$ & 0.049 & 0.042 & 0.017 \\
\hline $\mathrm{FN}$ & 61.2 & 73.7 & 68.6 & 68.6 & 71.6 & 22.0 & 0.395 & 0.870 & 0.395 & 0.802 \\
\hline UN & 29.9 & 70.7 & 27.6 & 63.0 & 111.3 & 32.6 & 0.002 & 0.589 & 0.768 & 0.008 \\
\hline NB & 0.1 & 13.8 & -6.1 & 69.6 & 86.3 & 116.5 & 0.015 & 0.135 & 0.069 & 0.520 \\
\hline RNB & -0.03 & 0.07 & -0.09 & 0.33 & 0.35 & 212.3 & 0.029 & 0.319 & 0.134 & 0.946 \\
\hline SUN & 13.7 & 20.1 & 6.4 & 26.2 & 24.2 & 25.3 & $<0.001$ & 0.773 & 0.007 & 0.578 \\
\hline NMIC & 49.2 & 67.5 & 62.4 & 75.6 & 108.8 & 30.7 & 0.159 & 0.326 & 0.809 & 0.080 \\
\hline EFM & 137.9 & 144.5 & 118.5 & 120.4 & 113.7 & 36.4 & 0.853 & 0.355 & 0.919 & 0.859 \\
\hline
\end{tabular}

RAN - rumen-ammonia nitrogen concentration (mg/dL); NI - nitrogen intake (g/d); FN - fecal nitrogen (g/d); UN - urinary nitrogen (g/d); NB - apparent nitrogen balance (g/d); RNB - relative nitrogen balance (g/g NI), SUN serum urea nitrogen $(\mathrm{mg} / \mathrm{dL})$; NMIC - ruminal production of microbial nitrogenous compounds ( $\mathrm{g} / \mathrm{d})$; EFM - efficiency of microbial synthesis (g of microbial CP per kg TDN).

C - control (without supplementation); NIT - supplementation with nitrogenous compounds; ST - supplementation with starch; NIT+ST - supplementation with nitrogenous compounds and starch; $\mathrm{AD}$ - supplementation with nitrogenous compounds and a mixture of starch and nitrogen which presented $150 \mathrm{CP} / \mathrm{kg} \mathrm{DM}$ (additional treatment).

$\mathrm{N}$ - effect of supplementation with nitrogenous compounds; $\mathrm{S}$ - effect of supplementation with starch; $\mathrm{N} \times \mathrm{S}$ - interaction between nitrogenous compounds and starch; ADIT additional comparison between treatments NIT+ST and AD.

Table 7 - Estimates common rate of ruminal lag and degradation of neutral detergent fiber $\left(\lambda\right.$, in $\left.\mathrm{h}^{-1}\right)$ and discrete lag for fiber degradation (LAG, in hours) according to the treatments

\begin{tabular}{|c|c|c|c|c|c|c|}
\hline \multirow{2}{*}{ Contrast } & \multicolumn{5}{|c|}{ Treatments } & \multirow{2}{*}{ P-value } \\
\hline & Control & Nitrogen & Starch & Nitrogen + Starch & Additional supplement & \\
\hline$\lambda$ & $0.060 \pm 0.005$ & $0.068 \pm 0.007$ & $0.040 \pm 0.004$ & $0.060 \pm 0.006$ & $0.054 \pm 0.006$ & 0.008 \\
\hline LAG & 4.64 & $4.16(89.7)$ & $7.10(153.0)$ & $4.70(101.3)$ & $5.19(111.9)$ & - \\
\hline
\end{tabular}

C - control (without supplementation); NIT - supplementation with nitrogenous compounds; ST - supplementation with starch; NIT+ST - supplementation with nitrogenous compounds and starch; AD - supplementation with nitrogenous compounds and a mixture of starch and nitrogen which presented $150 \mathrm{CP} / \mathrm{kg} \mathrm{DM}$ (additional treatment).

Values between parentheses represent the relative value (\%) as basis of control treatment (without supplementation). 
by nitrogen supplementation until the diet presents a $\mathrm{CP}$ content of $80-100$ g/kg DM (Lazzarini, 2007; Figueiras, 2008; Detmann et al., 2010; Sampaio et al., 2010). From this, the response to nitrogen supplementation would be not evident on intake, and the loss of nitrogenous compounds would become more prominent (Detmann et al., 2009). This pattern is corroborated by the increase in UN and SUN upon nitrogen supplementation (Tables 4 and 6).

The basal forage used in this study presented an average CP content of $82.4 \mathrm{~g} / \mathrm{kg} \mathrm{DM}$ (Table 1), which is close to the previously described CP levels. The RAN concentration in animals without supplementation was lower than the minimal concentration required for a proper fibrolytic activity in the rumen $(8 \mathrm{mg} / \mathrm{dL}$; Detmann et al., 2009). However, the stimulation of fiber degradation caused by supplementation with nitrogenous compounds could be considered low because the $\lambda$ estimate was increased only by 0.008 (Table 7), which did not cause an alteration in the ruminal digestibility of the NDF (Table 5).

The elevated TDN level caused by nitrogen supplementation (Table 5) appears to reflect increases in CP digestibility rather than better NDF utilization. This pattern is reinforced when we consider that supplementation with nitrogenous compounds increased the TDN intake but not the DNDF intake (Table 3). This also supports the fact that the animals supplemented with nitrogenous compounds did not present any increase in the NB (Table 6). It must be emphasized that nitrogen retention depends on the availability of energy in the metabolism (Lee et al., 1987; Schroeder \& Titgemeyer, 2008).

Figueiras (2008) developed a study under similar conditions and observed that supplementation with nitrogenous compounds increased the voluntary intake and ruminal digestibility of the NDF. However, the basal forage evaluated by those authors presented a CP content lower than that observed in this study (75.5 g/kg DM).

It was expected that starch supplementation for animals fed tropical forage could decrease the voluntary intake as observed by Costa (2009) and Souza et al. (2010). Non-fibrous carbohydrate supplementation can indirectly affect the fill effect of the diet by modifying the mass of non-degraded residues in the rumen as a reflex to alterations in fiber degradation and passage (Dixon \& Stockdale, 1999). This pattern was partially observed in this study because starch supplementation decreased the degradation rate of the NDF, increased the lag time for fiber degradation (Table 7) and decreased the ruminal digestibility of the NDF despite an absence of negative effects on the total digestibility of the NDF (Table 5). This behavior corroborates previous reports concerning the negative effects of NFC on the activity of fibrolytic enzymes (Bowman et al., 2004).

However, starch supplementation did not decrease the NDF or the pasture intake (Table 3), even though the ruminal degradation of the NDF decreased (Tables 5 and 7). This result implies that a substitutive effect on the pasture intake did not occur upon starch supplementation. When ruminant animals are fed low-quality forage, the substitution of forage by grain (or NFC supplements) is typically reduced compared with that observed for animals fed high-quality forage (Minson, 1990; Dixon \& Stockdale, 1999). The substitutive effect becomes lower as the forage availability decreases because the pasture conditions necessary to propitiate the maximal intake were not attained (Minson, 1990). The average forage availability in this study ( $2.8 \mathrm{t}$ of $\mathrm{DM} / \mathrm{ha}$ ) can be considered low. The low quality and availability of the forage appear to support the absence of a substitutive effect on the voluntary pasture intake when starch was supplied (Table 3). The average NDF intake observed in this study was $10.8 \mathrm{~g} / \mathrm{kg} \mathrm{BW}$, which is low compared with those observed by other authors during the dry season (Moraes, 2006; Figueiras, 2008), and this finding reinforces the concept that the pasture intake was not optimized.

Despite the decrease in NDF utilization in the rumen, starch supplementation improved the dietary level and intake of TDN (Tables 3 and 5). This improvement appears to be a direct result of the increase in intake (Table 3) and total digestibility (Table 5) of NFC. The apparent digestibility of the nonfibrous components of the diet is proportional to their intake (Van Soest, 1994). Therefore, this statement may support the improvement in NFC digestibility upon starch supplementation.

However, despite the increase in TDN intake, starch supplementation alone did not improve nitrogen retention by the animals (Table 7). Similar to previously presented arguments, an increase in available energy may not reflect an improvement in body tissue synthesis if there are limitations on the metabolic availability of nitrogenous compounds (Schroeder \& Titgemeyer, 2008).

The main effect of supplementation in this work is associated with the interaction effects between starch and nitrogenous compounds on the NB (Table 4). It was observed that only simultaneous starch and nitrogen supplementation could improve the retention of nitrogen by the body. Under productive conditions, this pattern would cause improvements in body weight gain. The RNB presented a similar pattern, although without a significant effect $(\mathrm{P}>0.10)$, with the highest value obtained upon simultaneous starch and nitrogen supplementation (Table 6). 
The NB and RNB can be associated with the patterns of other variables. Supplementation with starch and/or nitrogenous compounds did not affect the NMIC (Table 6), which is the main source of metabolizable protein (MP) for animals fed forage-based diets. In these circumstances, considering the MP as a direct source for body nitrogen accretion, the interactive effect between starch and nitrogenous compounds on the NB appears to represent an improvement in the efficiency of the utilization of MP into net protein rather than an increase in the MP supply.

According to Detmann et al. (2010), the supply of nitrogenous compounds in the rumen may increase the microbial growth on fiber, but it did not necessarily imply a significant increase in the microbial flow to the small intestine as was verified in the tropics by several authors (Lazzarini, 2007; Figueiras, 2008; Costa, 2009; Souza et al., 2010). In addition, Souza et al. (2010) reported that the effects of supplemental nitrogen and carbohydrates are interactive with regard to nitrogen assimilation. Both arguments appear to corroborate the results observed here concerning the NMIC (Table 6) and NB (Table 7).

When the control treatment was evaluated, there was no nitrogen retention by the animals despite the similar NMIC production to that of the supplemented animals (Table 6). The RDCP in the control group was negative, which indicates that the nitrogen flow in the abomasum was lower than the nitrogen intake. The rumen was under a negative nitrogen balance, and a significant amount of nitrogenous compounds was provided through urea recycling.

Among the several mechanisms involved in the regulation of urea transference to the rumen, the RAN concentration must be highlighted (Huntington \& Arquibeque, 2000; Marini \& Van Amburgh, 2003). Animals with low RAN concentrations will present a higher urea transference rate from the blood to the rumen. According to Kennedy \& Milligan (1978), the highest urea transference to the rumen in cattle would be obtained under RAN concentrations of approximately $5-8 \mathrm{mg} / \mathrm{dL}$. Considering the RAN concentration in the nonsupplemented animals $(4.46 \mathrm{mg} / \mathrm{dL})$, it is speculated that the MP could be carried to the liver for urea synthesis and recycled to the rumen instead of being deposited in tissues in the body. This result would be a possible mechanism to sustain RAN levels and microbial activity in the rumen (Costa, 2009; Detmann et al., 2010; Rufino, 2011).

When supplemental nitrogen was supplied, the demand for recycled urea in the rumen would decrease because the RAN concentration increased $(17.13 \mathrm{mg} / \mathrm{dL})$. This result caused a positive RDCP in the animals supplemented with nitrogenous compounds (Table 4). However, there was no improvement in the NB compared with that of the nonsupplemented animals (Table 7).

In ruminant animals, the efficiency of body protein accretion depends on the energy availability as well as the efficiency of metabolizable energy utilization depends on the availability of amino acids (Scales et al., 1974; Schroeder \& Titgemeyer, 2008). Nevertheless, nitrogenous compound supplementation reduced the demand for urea in the rumen, but MP would not be retained in the body, due to an inadequate metabolizable energy supply. The relative excess of MP in relation to the available energy would be eliminated, which will increase urinary losses, such as those verified in this study (Table 6).

Exclusive starch supplementation presented a pattern similar to that observed in the control group with a low RAN concentration and a negative RDCP (Table 4). However, in these circumstances, the requirement of the rumen for urea can be increased due to the higher level of degraded OM in the rumen (Kennedy et al., 1981) caused by the starch. This statement is supported by the lower RDCP of the animals supplemented with starch compared with that of the control animals (Table 4). The increase in energy intake caused by starch supplementation (Table 3) did not improve the NB (Table 4), possibly because there was a restriction on MP availability. This pattern appears to lead to an elimination of surplus energy through futile metabolic pathways (Poppi \& McLennan, 1995).

When both types of supplements were supplied together, the constraints presented above would not be observed because nitrogen supplementation increases the RAN concentration (Table 4) and decreases the displacement of MP for urea recycling to the rumen. Starch supplementation provides energy (Table 3) for MP retention in the body and increases the NB (Table 7), thereby confirming that accretion by body tissues is an interactive process where both the efficiencies of energy and the MP utilization are interrelated (Schroeder \& Titgemeyer, 2008).

The additional treatment was included in this experiment to evaluate whether additional nitrogen supplementation could improve the nutritional performance of animals supplemented with both starch and nitrogenous compounds (Table 2).

The inclusion of rapidly fermentable carbohydrates in the diet can favor the growth of NFC-fermenting bacteria to the detriment of fibrolytic bacteria (Carvalho, 2009). This event is called "carbohydrate effect," and it increases the competition for essential nutrients between the groups of bacterial species. This competition can compromise the utilization of insoluble fiber by fibrolytic bacteria, which present a lower growth rate and, consequently, a lower 
capacity of competition for nutrients than non-fibrolytic bacteria (Costa, 2006; Carvalho, 2009).

The carbohydrate effect was verified in this study by considering that starch supplementation decreased the ruminal digestibility (Table 5) and degradability (Table 7) of NDF. However, when both types of supplements were supplied together, the negative effect of starch reduced the carbohydrate effect (Table 7). Although without significance $(\mathrm{P}<0.11)$, additional CP supplementation to the animals supplemented with both nitrogen and starch increased the ruminal digestibility of the NDF by 0.088 (Table 5), which reflected an increase in both the dietary level (Table 5) and intake (Table 3 ) of the TDN. This finding indicates that the benefits of simultaneous supplementation with starch and nitrogen on nitrogen retention in the body (Table 6) could be further improved by alterations in the composition of the supplements and the resulting effects on other parameters, such as energy extraction from the NDF.

The difference between the treatments involving both starch and nitrogen supplementation with regard to the degradation rate of NDF was not evident (Table 7). Despite this fact, additional CP supplementation increased NMIC production (Table 6), which appears to indicate a decrease in competition between the fibrolytic and nonfibrolytic species in the rumen. In this case, although without significance $(\mathrm{P}>0.10)$, the higher MP supply from the NMIC increased the estimate of the NB by $24 \%$ compared with that of the animals supplemented with both starch and nitrogenous compounds.

According to Detmann et al. (2010), cattle production on pasture should be optimized when the effects of interaction between the basal forage and the supplements are maximized if the interaction effects are beneficial or minimized if the interaction effects are detrimental. By adapting that statement to the conditions of this work, we can affirm that the supplements given to grazing cattle during the dry season must be formulated to maximize the benefits of the interaction effect of the forage and the supplemental protein and energy to increase the nitrogen accretion and the weight gain of the animals. On the other hand, the composition of the supplements can also be manipulated to minimize some of the detrimental effects of supplementation on forage utilization (e.g., decreasing competition between fibrolytic and nonfibrolytic microbial species).

\section{Conclusions}

Supplementation with both starch and nitrogenous compounds to cattle grazing on low-quality tropical forage is characterized by an interactive effect that increases nitrogen retention by the animals.

\section{References}

BARBOSA, A.M.; VALADARES, R.F.D.; VALADARES FILHO, S.C. et al. Endogenous fraction and urinary recovery of purine derivatives obtained by different methods in Nellore cattle. Journal of Animal Science, v.89, p.510-519, 2011.

BOWMAN, J.G.P.; SOWELL, B.F.; SURBER, L.M.M. et al. Nonstructural carbohydrate supplementation of yearling heifers and range beef cows. Journal of Animal Science, v.82, p.2724-2733, 2004.

CARVALHO, I.P.C. Avaliação causal do "efeito proteína" sobre a atividade microbiana em substratos fibrosos insolúveis. 2009. 35f. Dissertação (Mestrado em Zootecnia) - Universidade Federal de Viçosa, Viçosa, MG.

CASALI, A.O. Procedimentos metodológicos in situ na avaliação do teor de compostos indigestíveis em alimentos e fezes de bovinos. 2006. 47f. Dissertação (Mestrado em Zootecnia) Universidade Federal de Viçosa, Viçosa, MG.

CHEN, X.B.; GOMES, M.J. Estimation of microbial protein supply to sheep and cattle basid on urinary excretion of purine derivatives - an overview of the technical details. Aberdeen: Rowett Research Institute, 1992. 21p.

CHIZZOTTI, M.L.; VALADARES FILHO, S.C.; VALADARES, R.F.D. et al. Consumo, digestibilidade e excreção de uréia e derivados de purinas em novilhas de diferentes pesos. Revista Brasileira de Zootecnia, v.35, p.1813-1821, 2006.

COSTA, V.A.C. Dinâmica de degradação in vitro da fibra em detergente neutro de forragens tropicais em função de suplementação protéica e/ou energética. 2006. 52f. Dissertação (Mestrado em Zootecnia) - Universidade Federal de Viçosa, Viçosa, MG.

COSTA, V.A.C. Desempenho nutricional de bovinos em pastejo durante o período das águas com suplementação protéica ou protéico-energética. 2009. 90f. Tese (Doutorado em Zootecnia) Universidade Federal de Viçosa, Viçosa, MG.

DETMANN, E.; VALADARES FILHO, S.C. On the estimation of non-fibrous carbohydrates in feeds and diets. Arquivo Brasileiro de Medicina Veterinária e Zootcnia, v.62, p.980-984, 2010.

DETMANN, E.; PAULINO, M.F.; VALADARES FILHO, S.C. Avaliação nutricional de alimentos ou de dietas? Uma abordagem conceitual. In: SIMPÓSIO DE PRODUÇÃO DE GADO DE CORTE, 6., 2008, Viçosa, MG. Anais... Viçosa, MG: DZO-UFV, 2008. p.21-52.

DETMANN, E.; PAULINO, M.F.; MANTOVANI, H.C. et al. Parameterization of ruminal fiber degradation in low- quality tropical forage using Michaelis-Menten kinetics. Livestock Science, v.126, p.136-146, 2009.

DETMANN, E.; PAULINO, M.F.; VALADARES FILHO, S.C. Otimização do uso de recursos forrageiros basais. In: SIMPÓSIO DE PRODUÇÃO DE GADO DE CORTE, 7., 2010, Viçosa, MG. Anais... Viçosa, MG: DZO-UFV, 2010. p.191-240.

DETMANN, E.; SOUZA, M.A.; VALADARES FILHO, S.C. et al. (Eds.) Métodos para análise de alimentos. Instituto Nacional de Ciência e Tecnologia de Ciência Animal. Visconde do Rio Branco: Suprema, 2012. 214p.

DIXON, R.M.; STOCKDALE, C.R. Associative effects between forages and grains: consequences for feed utilization. Australian Journal of Agricultural Research, v.50, p.757-73, 1999.

EL-SHAZLY, K.; DEHORITY, B.A.; JOHSON, R.R. Effect of starch on the digestion of cellulose in vitro and in vivo by rumen microorganisms. Journal of Animal Science, v.20, p.268-276, 1961.

FIGUEIRAS, J.F. Consumo e digestibilidade em bovinos em pastejo com forragem tropical de baixa qualidade recebendo níveis crescentes de compostos nitrogenados suplementares. 
2008. 29f. Dissertação (Mestrado em Zootecnia) - Universidade Federal de Viçosa, Viçosa, MG.

HENNESSY, D.W.; WILLIAMSON, P.J.; NOLAN, J.V. et al. The roles of energy-rich or protein-rich supplements in the subtropics for young cattle consuming basal diets that are low in digestible energy and protein. Journal of Agricultural Science, v.100, p.657-666, 1983.

HUNTINGTON, G.B.; ARCHIBEQUE, S.L. Practical aspects of urea and ammonia metabolism in ruminants. Journal of Animal Science, v.77, p.1x-11x, 2000.

KENNEDY, M.P.; MILLIGAN, L.P. The effects of dietary sucrose and the concentrations of plasma urea and rumen ammonia on the degradation of urea in the gastrointestinal tract of cattle. British Journal of Nutrition, v.43, p.25-140, 1978.

KENNEDY, M.P.; CLARKE, R.T.J.; MILLIGAN, L.P. Influences of dietary sucrose and urea on transfer of endogenous urea to the rumen of sheep and numbers of epithelial bacteria. British Journal of Nutrition, v.46, p.533-541, 1981.

LAZZARINI, I. Consumo, digestibilidade e dinâmicas de trânsito e degradação da fibra em detergente neutro em bovinos alimentados com forragem tropical de baixa qualidade $\mathrm{e}$ compostos nitrogenados. 2007. 52f. Dissertação (Mestrado em Zootecnia) - Universidade Federal de Viçosa, Viçosa, MG.

LAZZARINI, I.; DETMANN, E.; SAMPAIO, C.B. et al. Dinâmicas de trânsito e degradação da fibra em detergente neutro em bovinos alimentados com forragem tropical de baixa qualidade e compostos nitrogenados. Arquivo Brasileiro de Medicina Veterinária e Zootecnia, v.61, p.635-647, 2009.

LEE, G.J.; HENESSY, D.W.; NOLAN J.V. et al. Responses to nitrogen and maize supplements by young cattle offered a low-quality pasture hay. Australian Journal of Agricultural Research, v.38, p.195-207, 1987.

LENG, R.A. Factors affecting the utilization of 'poor-quality' forages by ruminants particularly under tropical conditions. Nutrition Research Reviews, v.3, p.277-303, 1990.

MARINI, J.C.; Van AMBURGH, M.E. Nitrogen metabolism and recycling in Holstein heifers. Journal of Animal Science, v.81, p.545-552, 2003.

MINSON, D.J. Forage in ruminant nutrition. San Diego: Academic Press, 1990. 483p.
MORAES, E.H.B.K. Desempenho e exigências de energia, proteína e minerais de bovinos de corte em pastejo, submetidos a diferentes estratégias de suplementação. 2006. 136f. Tese (Doutorado em Zootecnia) - Universidade Federal de Viçosa, Viçosa, MG.

PAULINO, M.F.; DETMANN, E.; VALENTE, E.E.L. et al. Nutrição de bovinos em pastejo. In: SIMPÓSIO SOBRE MANEJO ESTRATÉGICO DA PASTAGEM, 4., 2008, Viçosa, MG. Anais... Viçosa, MG: SIMFOR, 2008. p.131-169.

POPPI, D.P.; McLENNAN, S.R. Protein and energy utilization by ruminants at pasture. Journal of Animal Science, v.73, p.278-290, 1995.

REGAZZI, A.J. Teste para verificar a igualdade de parâmetros e identidade de modelos de regressão não-linear. Ceres, v.50, p.9-26, 2003.

RUFINO, L.M.A. Suplementação nitrogenada ruminal e/ou abomasal em bovinos alimentados com forragem tropical. 2011. 34f. Dissertação (Mestrado em Zootecnia) - Universidade Federal de Viçosa, Viçosa, MG.

SAMPAIO, C.B.; DETMANN, E.; PAULINO, M.F. et al. Intake and digestibility in cattle fed low-quality tropical forage and supplemented with nitrogenous compounds. Tropical Animal Health and Production, v.42, p.1471-1479, 2010.

SCALES, G.H.; DENHAM, A.H.; STREETER, C.L. et al. Winter supplementation of beef calves on sand hill range. Journal of Animal Science, v.38, p.442-448, 1974.

SCHROEDER, G.F.; TITGEMEYER, E.C. Interaction between protein and energy supply on protein utilization in growing cattle: a review. Livestock Science, v.114, p.1-10, 2008.

SOUZA, M.A.; DETMANN, E.; PAULINO, M.F. et al. Intake, digestibility and rumen dynamics of neutral detergent fiber in cattle fed low-quality tropical forage and supplemented with nitrogen and/or starch. Tropical Animal Health and Production, v.42, p.1299-1310, 2010.

Van MILGEN, J.; MURPHY, L.L.; BERGER, L.L. A compartmental model to analyze ruminal digestion. Journal of Dairy Science, v.74, p.2515-2529, 1991.

Van SOEST, P.J. Nutritional ecology of the ruminant. 2.ed. Ithaca: Cornell University Press, 1994. 476p. 